\title{
出雲大社の慶長度造営本殿について \\ RECONSTRUCTION OF THE MAIN SANCTUARY AT IZUMO-TAISHA SHRINE \\ IN THE KEICHO PERIOD
}

\author{
藤 沢 彰* \\ Akira FUJISA WA
}

\begin{abstract}
I propose a reconstructed model of the main sanctuary at Izumo-Ta isha Shrine in the Ke $i c h o$ period. It was $5 k e n$ (35 shaku, approximately 10.605 meters) wide, $5 \mathrm{ken}$ deep, a $k e n$ was equivalent to 7 shaku, and 6 jo 5 shaku 4 sun (approximately 19.816 meters) high. I presume that it didn't have a pillar that supports the ridge beam directly (munamot $i$ bashira), and it had a roof construction system based on one slightly curved beam (koryo) and principal rafter with king-strut (inoko-sasu).
\end{abstract}

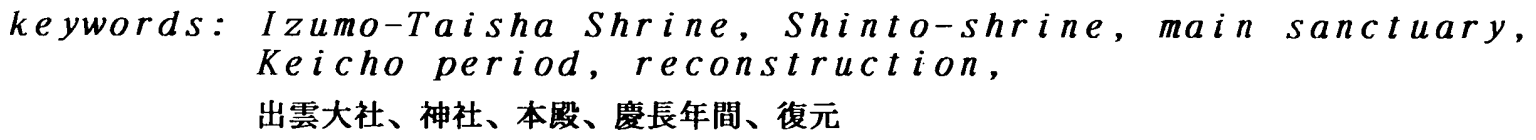

はじめに

豊臣秀頼の造営した出雲大社の慶長度本殿については、先学がす でにいくつかの重要な点を指摘している。また、近年では三浦正幸。 福本健司の両氏が復元図を作成し、はじめて慶長度本殿の具体的な 姿を提示した ${ }^{1)}$ 。筆者も「古代出雲文化展」出品のための復元模型 制作に参画する機会を得、復元を試みた ${ }^{2)}$ 。結果としてそれは三浦・ 福本両氏の復元案とは異なるものとなった。本稿では、拙案に用い た史料を提示し史料批判をくわえながらその解积を示し、あわせて 推測部分をふくめ、拙案作成にいたる考察経過を述べることにする。

\section{1. 先行研究}

まず、先行研究における慶長度本殿についての具体的な指摘をま とめ、問題点を明らかにしておく。なお、重複するものは原則とし て省略する。

福山敏男氏は「慶長十四年度造営の記録」、『懐虂談』などをよ りどころとして下記のような指摘をしだ)。

規模・部材寸法 棟高 5 丈 7 尺 4 寸 /桁行梁間とも 5 間( 30 尺、 1 間を 6 尺に設定)/四周の縁は正面 1 丈、側面背面 8 尺／

床高 1 丈 3 尺 4 寸/天井高(盢より) 1 丈 1 尺 1 寸/心柱の径 2

尺 6 寸 /向拝柱 1 尺 1 寸角/上段の高さ 7 寸

構造形式 礎石立/桧皮直／内部に上段下段あり／天井あり／ 畳数/四周に縁あり/階隐あり
装飾・彩色 要所に飾金物／天井に八雲の彩画 $/$ 柱 9 本は丹青 にて彩る/内部に金彩色の当社地図、競馬の絵をかく 以上の指摘のなかで問題と思われるのは、平面規模である。複数 の史料に桁行梁間とも5間という記述はみられるが、1間をいくら に設定するかについては論拠を示さず 1 間を 6 尺としている。

川上貢氏は、慶長度の次の造替にあたる寛文度の造営記録「御造 営日記」(史料については2.5項参照)を分析し、構造形式について 以下の点を指摘した ${ }^{4)}$ 。

構造形式 組物は出組/床下は羽目板張り／大梁上に束柱をた て、二重梁を組んで中間の母屋を支える方法は寛文度から採用 された(したがって慶長度は束柱を用い二重梁を支える架構で はなかった)〔( )内は筆者〕

出組の採用と小屋構造の指摘は、復元設計にとって重要な意味を もつ。

稲垣栄三氏は「杵築大社只今御座候仮殿造御宮立間尺覚」(史料 については2.3項参照)によって、かなり詳しい規模・部材寸法と装 飾・彩色などについて明らかにした5)。

規模・部材寸法 平面は 5 間四方/礎石から箱棟までの高さ 5 丈 7 尺 4 寸 /千木までの高さ 6 丈 5 尺 4 寸/四周の緣は正面 1

丈、側面背面 8 尺/心柱の径 2 尺 5 寸/側柱の径 2 尺 2 寸 5 分 /桧皮軒厚さ 2 尺

構造形式 礎石/桧皮莫／箱棟／天井あり／四周に縁あり／階 
隐あり/階段15級

装飾・彩色 内部の柱は朱叙り、外部の柱は黒漆真叙り/天井

に八荟の彩画をかく/切妻破風に彫刻を施した金物あり

さらに、稻垣氏は福山氏の研究を引用して床高は1 1 丈 3 尺 4 寸、 天井高は 1 丈 1 尺 1 寸であり、床の高さが天井の高さより 2 尺あま り高いことを指摘し、「高床らしさを示すのは全体の高さなのでは なく、むしろ地上より床までの高さが床上の高さよりも高く造られ ていること、それによって建物の姿が㪕快にみえることでなければ ならない」とし、「噔長の本殿は細部に新しい試みを施しながら、 全体としてはかろうじて伝統的な比例を失わなかったといえよう」 と結論した。

三浦。福本両氏は基本的な規模。形式は稲垣氏の紹介した「杵築 大社只今御座候仮殿造御宮立間尺覚」に依抱し、新出史料に検討を くわえ以下の点を指摘した ${ }^{6)}$ 。

視模 平面 5 間(32尺 5 寸)四方（1間を京間 6 尺 5 寸に設定）

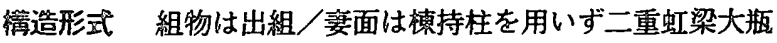
束 /二竍/知柱を用いる

装飾・彩色 垂木架に八双型の飾金具を打つ／両妻壁に龍二匹 （長さ 4 間)と雲水の彫物を飾る/階隐に基股を飾る／柱、長押、 敨居に布着せして、内側は朱塗り、外側は黒漆塗り

ここで問題になるのは、1 間を京間 6 尺 5 寸に設定し、平面規模 を32尺 5 寸四方としたこと、裹面を二重虹梁大瓶束としたこと、で ある。そして、慶長度本殿について次のように結論した。(1)慶長度 本殿は古式の大社造とは全く異なり、大社造とは言いがたいはどで ある。(2)寛文造営の初期の段階で幕府の提示した計画案(以下、寛 文度幕府案）【図 $17^{7}$ は、庱長度本殿の意匠を源厚に引き継いで いる。(3)現本殿(延等度造営)の妻旍は、度長度本殿の二重虹梁大瓶 束のなごりである。(4)現本殿は慶長度本殿をもととして、寛文度造 営の際に江戸幕府の工匠による復元考察の結果である。

ここで示された藂長度本殿および現本殿の位置付けに、筆者は異 なる見解をるっているが、拙案を提示したあとに述べることにする。

\section{2. 復元边数}

次に復元の基礎となった主な史料を紹介する。

\section{1 「杵築大社近郷絵図」(図 2】部分)}

北島家所蔵であり、おもてに「庑長十四年御造営之図」とある。 よく似た図柄の絵図が千家家にも伝わり、「宽永御絵図」と呼ばれ ている ${ }^{8)}$

北島。千家両家に伝わる絵図は、三重塔9)。鐘楼。一切経堂など を描いて出雲大社の神仏習合の状況を伝え、従来、噔長造営当時の 景観を示すと考えられてきた。しかし、最近の千家和比古氏の研究 10)により、両絵図之も寬文度造営が本格化する宽文 4 年(1661)10 月に、造替以前の状況を記録するため、松江住の絵師狩野(西山)久 三郎に命じ下絵を作成し、のちに清画したものであることが明らか になった。描写内容は寬文 4 年当時の实景とは言いきれず、神仏習 合の状況を記録するための復元的描写をも含み、いっぽうで復元描 写されなかった建物も混在する絵図であることが指摘された。

慶長度本殷、およびほかの社殿を含めた境内を復元するにあたっ ては、考察の余地を多分にのこす絵図ではあるが、当時の状況を視 覚的に伝えるものはほかになく、基礎史料とした ${ }^{11}$ 。

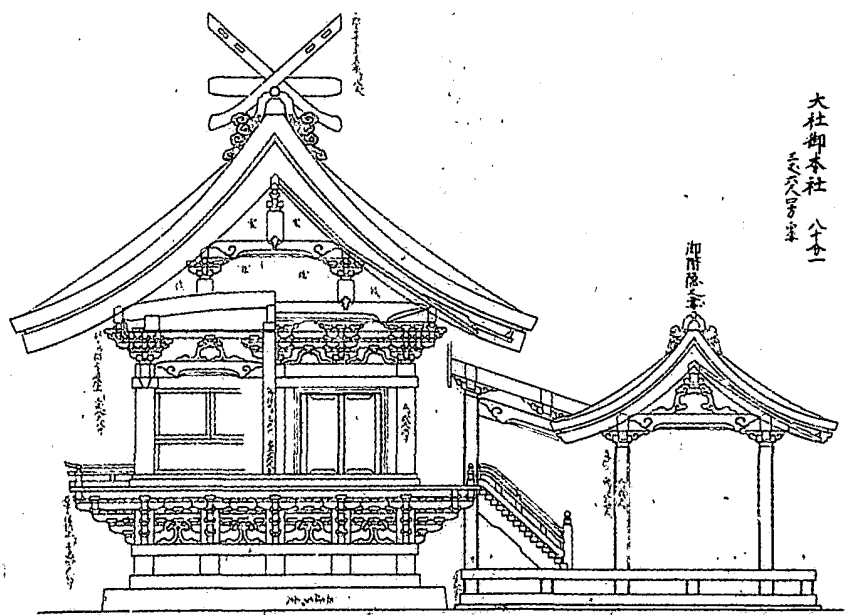

【図 1】出雲大社之図(寞文度幕府案)『古図にみる日本の建築』より

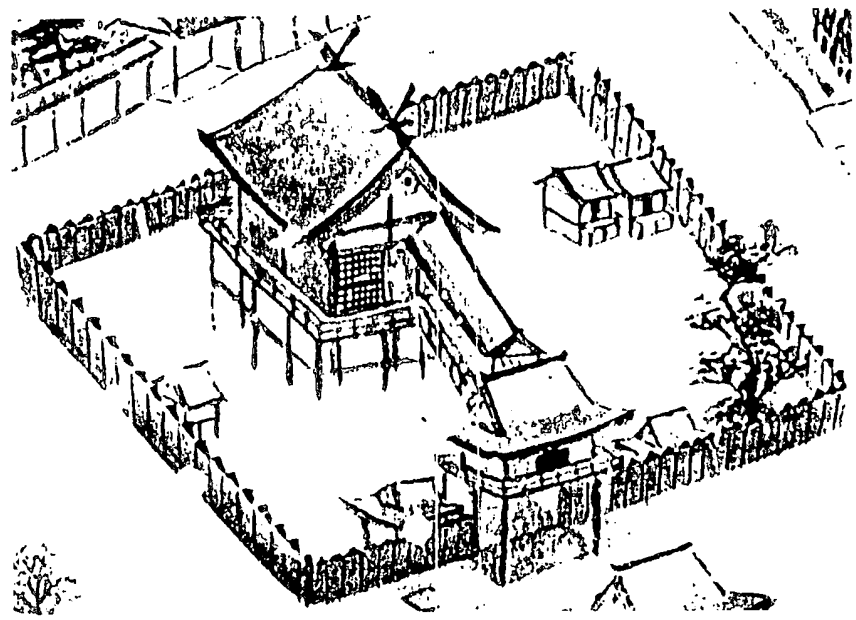

【図 2】杵築大社近郷絵図(部分)

\section{2 「慶長造営御宮立間尺〈佐草〉自清控」〔【史料 1】〕}

正保 3 年(1646)11月 1 日の年紀があり、出雲大社が所蔵する。後 述するように、佐草自清は北島国造家の上官で、晃文度造営では幕 府との折衝、造営計画の立案・遂行などにおいて中心的役割を果た し、寬文度造営の記録「御造営日記」(2.5項参照)を残した。現在 伝わるものは、出雲大社職員であった矢田豊雄氏が筆写したもので、 自清の控自体は所在不明である。今回の復元にあたって、はじめて 千家氏によって紹介され、詳細な史料批判がくわえられた ${ }^{12)}$ 。そ れによれば、原文の写し間違えなどがあるかもしれないが、次項で 紹介する「杵築大社只今御座候仮殿造御宮立間尺覚」と対照しても おおきな矛盾はなく、ほぼ信頼して良いものである、と結論された。 従来知られていたこの種の慶長度社殿に関する記録より数段詳しい 記述があり、今回の復元では最重要史料となった。

建物によって情報に精租の差があるが、当時存在した本殿をはじ めとする諸社殿の規模・部材寸法を記し、また、慶長13年(1608)ま であったが、その後退転した社殿の記録もある。末尾に「右の通り なれ共、今度、国守松平出羽守殿、御改被成候帳之写」「奉行 落 合彦左衛門尉／大工頭 竹内右兵衛尉／画工 大田弥兵衛尉」「正 保三年丙戌霜月一日」とある。正保 3 年は庱長度社殿の建て直しを 幕府に申し出た最初の年であった ${ }^{13)}$ 。次に、本殿にかかわる部分 のみ摘記する。

\section{一、左記正保三丙戌霜月記ニ云フ}


一、本社うちのり五間四方、但し京間二五寸

一、志ん柱さし渡し二尺六寸

一、がはの柱さし渡し二尺式寸五分

一、天井高さ轠より一丈一尺一寸

一、上段ノ高さ七寸

一、石よりゆかまで高サ一丈三尺四寸

一、ゆかより貫ノけた迄一丈七尺

一、のきノけたより箱棟まて二丈七尺 (岦口五丈七尺四寸

一、えんの廣さ 両脇渡八八尺宛、前八一丈

一、柱口より軒口迄一丈四尺

一、軒のあつさ二尺

一、むねの長九間

一、きさ階〈よこ式間半、長さ三間〉但、きさはし数十五

一、ごはいノはしら一尺一寸四方

（〈內内割り書き、以下おなじ）

2.3 「杵築大社只今御座候仮殿造御宮立間尺覚」【【史料 2】)

すでに述べたように、稲垣、三浦、福本各氏が用いた史料であり 14)、慶長度社殿に関する記録である。内容は【史料 1】とほとん ぞ矛盾しない。ただ、志ん柱(心柱)の径が【史料 1】では2尺6寸、 【史料 2】では 2 尺 5 寸となっている。次に、本殿にかかわる部分 のみ摘記する。

一本社内のり五間四方

一柱九本〈心柱さし渡シ武尺五寸 かはの柱さし渡シ武尺武寸五歩〉

内八朱外八黒漆真塗

一縁ノ広サ〈両脇後八八尺宛／前八壱丈〉

一石口上り箱棟迄高サ五丈七尺四寸

千木迄ノ高サ六丈五尺四寸

一棟ノ長サ九間

一檜皮蒀軒ノ厚サ武尺

一二重垂木さかわ金物

一切妻破風板大金物彫物〈龍二足つれ/雲水彩色〉

一はしかくし〈横式間半長サ三間檜皮莫きさはしの数 十五らんかんぎほうし金物慕俣ほり物〉

一内殿天井絵八雲七つ極彩色

一こみはりつけ金〈絵極彩色〉

\section{4 「口上之覚」(仮称)【【史料 3】〕}

寛文度造営の準備中である寞文 2 年(1662) 6 月16日付、佐草宮内 (自清)、嶋市丞(千家国造家上官)連名、奉行所あて書状の控えで、 一部に慶長度本殿に関する記述がある。先に三浦氏が用いた史料で あるが、三浦氏は島根県立図書館所蔵謄写本 $\left.{ }^{15}\right)$ によっている。こ こでは千家家所蔵本 ${ }^{18)}$ を紹介する。

仮殿造之宮二而御座候得共〈五間四方高文／六丈五尺四寸〉柱 長押敷居〈布きせ内は朱/外は黒狳〉彫物〈南破風二龍 $/$ 二正 連長サ／四間宛大工八其節京都之／良匠茶木久左衛門仕候〉組 物絵〈内殿金ノ張付／極彩色〉金物此外末社等応之

2.5 「御造営日記」

北島国造家の上官、佐草自清が記した寛文度造営の記録で、佐草 平安氏が所蔵する ${ }^{17}$ 。寛文度造営における、幕府との折衝、資金・
用材の確保から社殿の形式決定までの各種打ち合わせ、造営経過が 詳練に記されている。寛文度本殿の形式決定の過程で比較参照した 慶長度本殿に関する記述もみられる。論述をすすめる都合上、ここ で「御造営日記」を一括して紹介するのではなく、以下必要に応じ 適宜引用することにする。

3. 規模と部材寸法について

本殿の規模と部材寸法は「慶長造営御宮立間尺〈佐草〉自清控」 【史料 1 】「杵築大社只今御座候仮殿造御宮立間尺覚」【史料 2】 によってかなり明らかになる。

柱間を桁行梁行とも5間とすることは諸史料に一致する。最大の 問題点は平面規模において、1間をいくらに設定するかであろう。 福山氏は 1 間を 6 尺とし、30尺四方とした。福山氏の用いた寸法 を記した各種史料に 1 間を 6 尺にする根拠は記されていない。ただ、 「御造営日記」の寛文元年11月14日条に、「京間六尺五寸八中古よ りの事也、昔八六尺一間也」とある。また、京間の採用に関しては、 『匠明』所載の天正度本殿の指図に「京間五間四方有」と書き込み がある ${ }^{18)}$ 。しかし、他にそれより以前のこととして 1 間＝6尺を 謳った史料は見当たらない。

福本氏は京間の 1 間 $=6$ 尺 5 寸を採用し、32尺 5 寸四方とした。 その理由として、慶長度本殿が豊臣秀頼の造営であり秀頼の工匠が 京・大阪の大工であること、毛利輝元の造営した天正度本殿(京間 五間四方)より秀頼の造営した慶長度本殿が小さくなるとは考えに

くいこと、をあげた。

さて、ここで注目されるのは【史料 1】の「本社うちのり五間四 方、但し京間二五寸」という記述である。これは、平面の基準にな る 1 間の長さを京間 6 尺 5 寸に 5 寸を加え、 7 尺にすると解釈でき る。したがって平面は35尺四方ということになる。

1 間 $=7$ 尺を示す史料は他に見当たらないが、「御造営日記」宽 文 4 年閏 5 月 23 日条に寛文度造営の斤屋の設計を見直す記事があり、 庁屋丸柱さし渡シ一尺二寸八七尺間、十五間ノ差図、去年六尺 五寸二仕替申二付、柱ふとく見苦二付、さし渡シ九寸二義定仕 候

と記す。これによれば、寛文度庁屋は初め 1 間＝7尺で設計され、 のちに 6 尺 5 寸に変更されたという。当初の 7 尺間は慶長度造営の 影響ではなかろうか。

【史料 1】【史料 2】をもとに、規模と部材寸法をまとめると以 下のようになる(ただし、心柱径は【史料 1】を採用)。

規模・部材寸法

- 桁行梁行 5 間四方(35尺四方、 1 間 $=7$ 尺) / 縁の広さ 正面 1 丈、側面背面 8 尺/軒の出 1 丈 4 尺/軒の厚さ 2 尺/棟の長 さ 9 間(63尺)/階 15 級 横2.5間(17.5尺) 長さ 3 間(21尺) ・礎石より床までの高さ 1 丈 3 尺 4 寸/床より軒桁までの高さ 1 丈 7 尺/軒桁より箱棟までの高さ 2 丈 7 尺/礎石より箱棟 までの高さ 5 丈 7 尺 4 寸/礎石より千木までの高さ 6 丈 5 尺 4 寸/天井高(畳より) 1 丈 1 尺 1 寸 / 上段の高さ 7 寸

- 心柱径 2 尺 6 寸/側柱径 2 尺 2 寸 5 分/向拝柱 1 尺 1 寸角

4. 構造形式について

すでに指摘されていることだが、「御造営日記」寛文 4 年閏 5 月 
24日条、同 7月13日案によれば、廃長度本殿には磴石を用い、床下 は羽目板張りで、階隐が存在した。また、それらの採用は廢長度か らのことであり、「万夢慶長ノ社より古法を背候䩧」(悘文 4 年閏 5 月24日条)とある。

\section{。「御造営日記」总文 4 年(1664)閏5月24日条}

白日 昨日御本社を始庁屋等の地割差図吟㙅被成旨国造殿へ佐 草長谷披潞、就夫御本社御床の下天正八年仮段造営の社迄八如

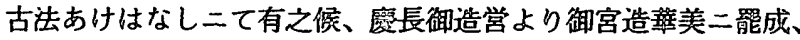
御床の下迄はめ板在之候、(中略)当社も正御宮造迄八礁二て

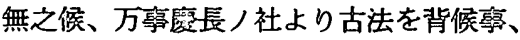

。「御造営日記」窞文 4 年 7月13日采 御本社の木形今日迄二調、圭代の手本二仕永御宮立の核子見世 可申ため四方のは板又は階かくしも不仕候、御本社二階かく し仕候事应長御造営の宮より始り申倓、

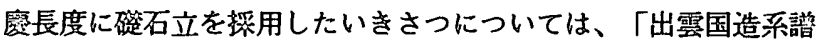
考」191第四十二世国造国経臣の項に、

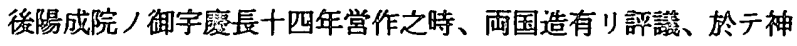
前二令御占任七圆二、始メテ而為不礎卜矣

とあり、神前において御占の圈をとって㨙否を決定したという。 本殿形式に新手法が留入されたのは噔長度からであり、寞文度造 営ではそれらを古式に戻すかが険討されている。しかし、上記の礎 石。羽目板。階鿵の 3 点は、樯造上の合理性、使い勝手の上から評 価されたようで、いずれも否定されず、筧文度でも踏放された。こ こで重要なことは、大社側の舅文度本殿の設計過程においては、䧹 長度本殿がたたき台となり、何かと比銑されていることである。

棈造形式の点でなによりも問題となるのは組物と翌飾である。

三浦氏は「出雲国造系謭考」によって度長度本殿の組物は出組で あることを論証しだ20)。

「御造営日記」倪文元年11月14日条に賽文造営最初期の大社宮大 工と幕府作事方被官大工鈴ホ三郎左衔門の打ち合わせの記毫があり、 宮両大工鈴木三郎左衛門へ参儿、大社御宮立組物定て出組二て 可有之候、二手先八有間影亡申候

と記す。大社の組物は出組であるべきで、二手先は受け入れられな いとの大社側宮大工の意向が記されている。これに対して鈴决三郎 左衛門は「二手先も日本樣二地割可仕」と述へ、二手先を铨討する ことを提䋈し、芧実、後日示される幕府案『图 1】では二手先が採 用されている。賽文ころの大社宮大工には「大社本殿の組物は出組」 という認識があったようである。

本殿の組物が出組となると、大社造の特徵である幄面から突出し た相持柱は用いることが因難になり、妻面の端成は現本殿〔延亭元

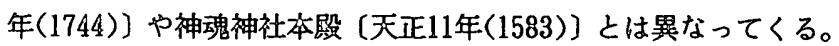

三浦。福本案では贸飾に二重虹梁大瓶束を用いている。その理由

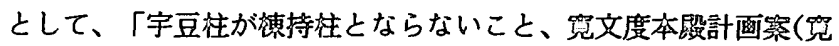
文度幕府案)において二重虹梁大瓶柬が用いられていること、同時 期の他の豊臣秀䡩造営による神社本殿にも二重祆梁がつかわれてい ること」〔( )内は筫者〕をあげている21)。

しかし、咅を二重虹梁大瓶束とすることには問題がある。

倪文度造営では寬文 2 年 2 月に幕府䇣の基本設計が整い、2月 29 日に地割清㕷と制差図を江戸において大社側に一覧させている ${ }^{22)}$ 。 その後、4月 5 日に幕府は寬文度造営に対する基本方針 9 力案を提
示する。幕府の方針のうち、大社にとって抜き差しならない重大な 問題点は、新造は本殿だけであり他の社殿は修復にとどめるという ことであった。これに対して、大社側は本殿の造替だけにとどめる のではなく、全社殷の新造、境内全域の拡張整備を重视て䧋徫し、 結界的に幕府の合意を取り付けることに成功している。

方針の転換とともに幕府の提示した本殿の基本設計も大きく見直 され、最終的には幕府䋈とは全く異なる筧文度本殿が造営された。 その設計見直しの過程で、先述したようにしばしば庋長度本殿が引 き合いに出されているのである。

寞文度本殿の基本設計の見直しは、寛文 4 年閏 5 月から本格化す

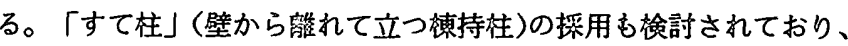
「御造営日記」寬文 4 年閏 5 月24日条に、

此度御正殿造大そう成屋扫二て候故、德本両ノ行二内外宮のこ とくすて柱可仕哉、卫八榷ホ二て能候八んやと半右殷佐草なと 吟㙅仕、勿論すて柱不苦重二候へ共、御往九本二定り在之上八、 不入物か

とあって、榑木と両術に肘木を入れるだけで良いのか、あるいは

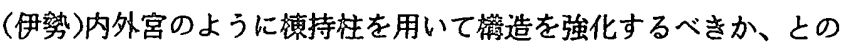
墥論がもちあがり、結局、柱は九本と決まっているので、見合わせ ることに落ち着いている。設計が見直され、決定して行く過程で、 組物、妻面の樯成については、つづけて閏 5 月24日条に、

筲本八博不両衙先はかり二仕候八見惩もつよミも能候八んと、 大工茂左衙門佐草相談の趣、半右殿へ申談傋定仕候、太形二て 樣子かつてん被申候、

とあり、この時点の計画では、肘木を楎木と両俗に入れるだけの簡 潔なものであったことがわかる。「大工茂左簿門」は同月19日に到 着したばかりの江戸大工菘井茂左衙門であり、「佐草」は佐草宮内、 「半右殿」は公江灌造営奉行岡田半右衔門である。また、指図だけ ではなく材形(模型)を用いて釦討が加えられていることも注目され、 最終的に不形は 7月13日に完成し、将来の手本とされた ${ }^{23) 。 ~}$

釦討はさらにつづき、6月16日案に、

同日御本社不形いかにも堅ぬつよく被仕候二しかし在候へ共、 梁ヨ左右の竹ばかり二てつなき候てハよハミたるへきと為候間 中哪二通り入、又其二つか柱 7 立候て小屋梁二职付候八八可然 候八ん哉と佐草差図申候へは、大工庄助いかにも尤と候て中衔 右の差図ノ通り仕候、氺代残シ置木形の亨二候間随分被入念倓 へと申渡し候

とある。梁を左右の衔につないだだけでは弱いので、中衙を入れ束 柱をたて、小屋梁に职り付けることを佐草宮内が提突し、大工生助 (江戸大工日向少助)も同意している。

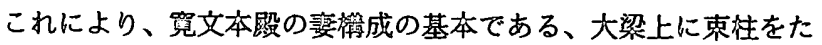

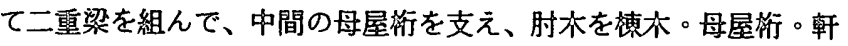
哘の下に挿入する形式が成立した(実際には时不部构は直線枋になっ

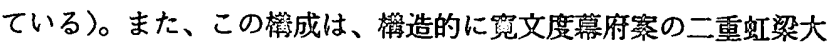
瓶束の手法に通じ、かつて、これを江戸において一㹂したことのあ る佐草宮内が提案していることは注目される。

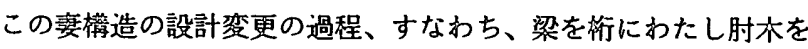
博木と両析の下に入れるだけの簡潔な形式から、大梁上に束往をた て二重梁を組んで、中間の母屋到を支え、肘木を槙木。母屋朔。亁 桁の下に插入する形式への变化は、大社側の基本設計見直しの素颈 


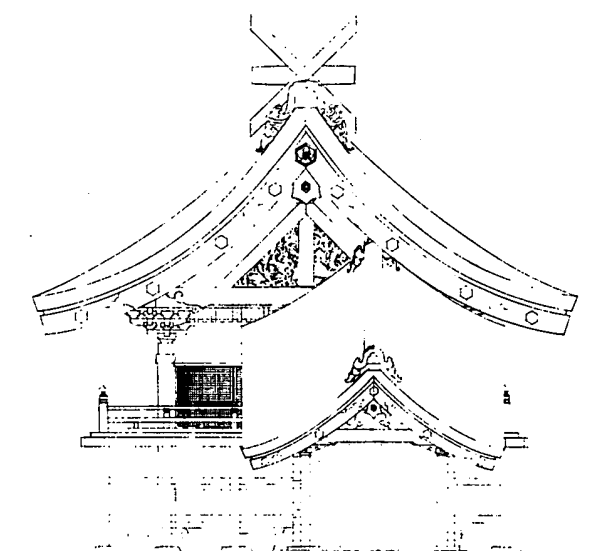

【図 3】出雲大社. 慶長度本殿 復元図(正面)

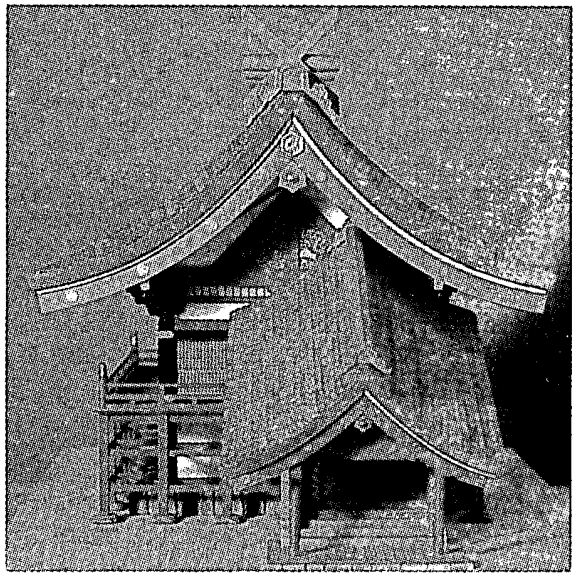

【写真 $1 】$ 出雲大社. 慶長度本殿 復元模型(正而 1/150)

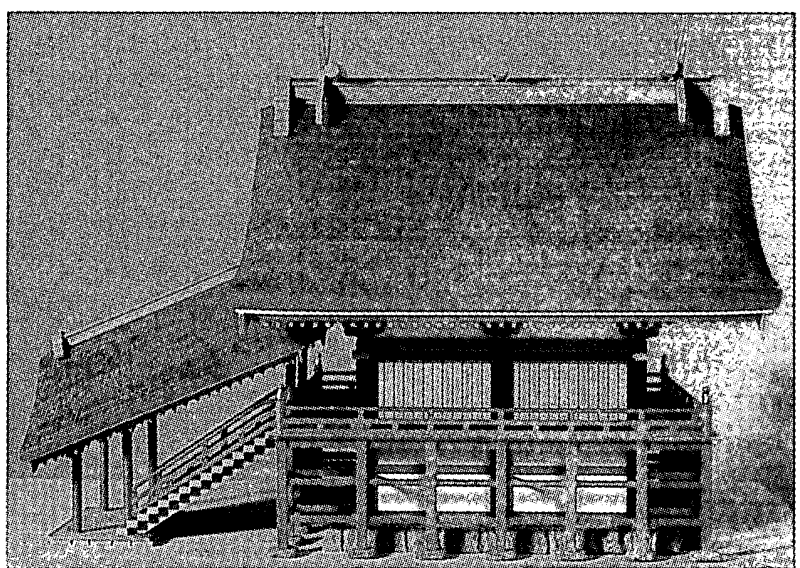

【写真 2】出雲大社. 愛長度本殿 復元模型(側面 1/150)

に、寛文度幕府案があったのではないことを示唆している。つまり、 簡挲な構造から寬文度幕府案に通じる複雑な構造への設計変更は、 最初から複雑な構造が素案にあったのではなく、数度の検討の結果、 かつてそれを見たことのある佐草宮内によって、寛文度幕府案の妻 構造に近いものが提案され採用されたことをものがたっている。ま た、寛文度本殿の基本設計案は、幕府の工匠中心ではなく、大社側 が主導権を握りながら検討が重ねられ、提案がくりかえされ決定さ れている。大社側の素案は寛文度幕府案ではなく、当時存在してい た慶長度本殿と考えるべきであり、したがって、慶長度本殿の妻面 はかなり簡潔な架構であったと推測される。よって、大梁・束柱・ 二重梁・母屋行の妻構成は寛文度からの新儀であり、慶長度本殿は
別の形式であったと考えられる24)。

しかし、以上の考察だけで慶長度本殿の妻面の形式を確定するこ とはできない。出組の採用、宇豆柱は棟持柱とならない、そして、 大梁・束柱・二重梁・母屋桁の妻構成とはならない、という点を基 に、あとは「杵築大社近郷絵図」【図 2】の描写を参考に推測する しか方法はない。

【図 2】では、本殿妻面の中央に大梁から棟木までのびる垂直線 がはっきりと見てとれ、梁は二重梁ではなく大梁一本だけで、組物 は見えない。組物は描写が省略されたと考えられても、妻中央の垂 直楾を棟持柱と解积するわけには行かない。文献史料之絵画史料が 相互に矛盾することになり判断に苦しむが、復元では、妻面の構成 を出組・虹梁・豕双首とした ${ }^{25)}$ 。二重虹梁大瓶束として、妻中央 の垂直線の存在と一重梁であることに目をつぶるのは、慶長度社殿 の状況を視覚的に伝える唯一の絵画史料を軽視することになろう。

構造形式についてまとめると以下のようになる。

構造形式

礎石立／桧皮莫／箱棟／千木／内部に上段下段あり／天井あり ／畳敷／四周に縁あり/階隐あり／床下は羽目板張り／組物は 出組／宇豆柱は棟持柱としない／妻は虹梁、豕双首／二軒／柱 は知柱を用いる

\section{4. 䒾飾と彩色}

䒾飾と彩色については、妻に飾る龍の彫物が問題になろう。 「口上之覚」【史料 3】(千家家所蔵本)に、

彫物〈南破風二龍／二疋連長サ／四間宛大工八其節京都之／良 匠茶木久左衛門仕候〉

とあって、南破風(南妻面)に龍が二匹飾られていたという。ところ が島根県立図書館所蔵滕写本には「彫物〈両破風二龍/二正連 $\cdots$ 」 とあって、龍は両面の妻に飾られていたことになる。千家家本と図 書館本の信頼性については註16に述べた。「南」と「両」の一字の 相違だけではなんとも言いがたいが、復元では千家家本にしたがい、 南妻面だけに龍の彫物を飾った ${ }^{26)}$ 。

䒾飾と彩色についてまとめると以下のようになる。

装飾・彩色

要所に飾金物あり/天井に八雲の彩画をかく/内部に金彩色の 当社地図、競馬の絵をかく/柱、長押、敷居に布着せして、内 側は朱塗り、外側は黒漆塗り/切妻破風に彫刻を施した金物あ り/南妻面に龍二匹と雲水の彫物を飾る／階隐に蟇股を飾る

むすび

以上の考察をもとに復元した出雲大社の慶長度本殿は【図 3】

【写真 1】【写真2】のようになる(ただし、内部および細部は復 元していない)。

最後に、本論文の範囲を越える点もあるが、慶長度本殿、寛文度 幕府案、寛文度本殿(延享度現本殿にも通じる)の位置付けについて 私見を述べてむすびとする。

(1)慶長度本殿は、礎石・床下の羽目板・階隱などの新規採用、出 組の採用、宇豆柱を棟持柱としない、彩色、妻の龍の彫物など、 古式の大社本殿に見られない構造形式と、かなり強い装飾性が 指摘できる。 
(2)宽文度幕府案『図 1】は規模。薄造形式。意匠の面で鹿長度本 殿を引き継いでいない27)。寛文度幕府案に関しては、むしろ 寛永21年(1644)造営の日御碕神社社殿(篪川郡大社町)との関連 が想定される ${ }^{28)}$ 。

(3)寛文度本殿は、幕府。松汇蒗。出雲大社の造営担当者、江戸。 京都。松江。杵築の職人の協力のもとに実現したが29)、その たたき台となったのは慶長度本殿と考えられ、基本設計の見直 し、決定の過程で主尊的役割を果たしたのは松江簿。出雲大社 の造営担当者である。

(4)寛文度本殿(佂享度現本殿)の势清造は、基本設計見直しの過程

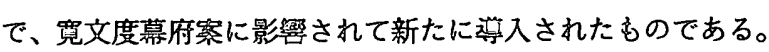

\section{謝辞}

本稿を執等するにあたり、千家和比古(出氶大社)。和田㔛有(米子 工業高等専門学芿)。島根県教育委員会。島浪県古代文化センター の方々に数多くの史料を提供していただき、また、貿重な御教示 を睗りました。ここに記して謝意を表します。

註

1 ）三浦正幸「出雲大社庑長度本殷の復元史料一出雲大社本殿の復元研究 (其一) -」、福本健司「出雲大社庭長度本殷の復元考察一出零大社本臤の

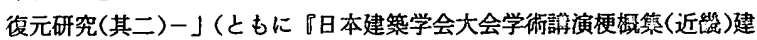
築歷史・恚匠』1996年)。それぞれ著者名は単記になっているが、ここで は一連の共同研究として扱い復元は共同案とさせていただく。

2)「古代出雲文化展」東京展 97年4月26日 6月8日 於賁武美術官、島根展 97年7月5日 8月24日 於島根県立八雲立つ風土記の丘资料館。島根県立博 物館、大阪展 97年11月18日 12月21日 於大阪市立美街館。平安時代中期 の本殿椺型 $(1 / 150$ )、鏡合時代前期(宝治頃)。江戸時代前期(庭長頃)。扛 戸時代中期(筧文頃)の境内建筑模型(いずれも1/150)を作成した。監修 千家和比古(出雲大社)。和田穷宥 (米子工業高等禀門学校)。島根県教育妥 員会、設計協力 畐島䢂幸(京都大学大学院)。ただし、平安時代中期の本 殷模型は、監修 福山敏男、大林組復元設計による。

3）福山敏男「出雲大社の金埨造営図」、「神社建築一大社造微原武論一」、 「山陰の神社建筇」(以上、『神社建築の研究』福山敏男著作管四 中央公 諭美術出版 1984)、同「出雲大社の社殿」(『日本建築史研究』量水留房 改訂版 1972)など。なお、「庭長十四年度造営の記録」(「神社建筑一大 社造後原試論一」が、具体的にどの史怙をさしているのかは明らかでな い。また、「正保三年の杵築大社只今在之御宮之間尺党は庭長十四年度造 営の社殿について記したものである。」(「出雲大社の社殷」)とあり、内 容の一部を紹介している。後述する「度長造営御宮立間尺〈佐草〉自清控」 (『史料1】)とは表題が異なっており、別史料と思われるが、内容は矛盾 しない。

4) 川上貢「出需大社の建築」(上田正昭編『出雲の神々』筑摩管房 1987)。

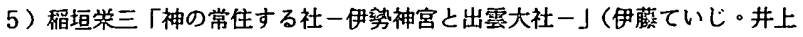

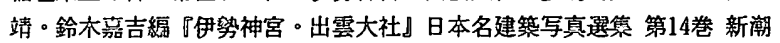
社 1993\%。

6 ) 三浦・福本前掲詥文。

7)「出露大社図」一巻〔元䘵15年(1702) 甲良宗貞写 真京国立幛物館所葴、 国立歷史民俗博物館獁 咕图にみる日本の建築』至文堂 1989 所収了が、

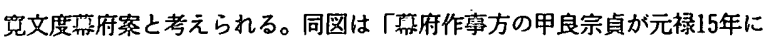
「修理」が持っていた图を編小して写したもの」(『古图にみる日本の建 築』図版解説、演島正士執管)であり、また、「(宽文度造営)初期の段階

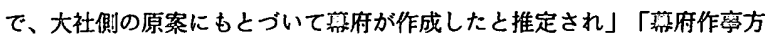
では地割(平面、立面、断面の設計)を大工頭鉿木修理が、不割(部材寸法、

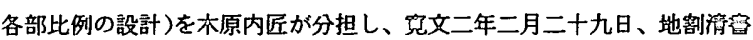
ならびに剓差図が完成しており、大社側に一䝂させている」(川上前揭論 文)。「御造営日記」(本文2.5項参照)宽文 2 年 2 月 14 日条、同 2 月29日条、 同 3月 6 日条などに閣臬記率がある。

8) 千家和比古「出雲大社の、いわゆる神仏習合を伝える絵图の梌討」(『古 代文化研究』第 4 号 島根県古代文化センター 1996 所收)によれば、聚面
に「宽永御口口(絵図力)」の貼り紙がある。なお、「筧永御絵図」の由来、 北島家所蔵「庱長十四年御造営之図」との異同については、同詥文に詳し い考察がある。

9) 名草神社三重塔(兵庫県兹父郡八鹿町石原大永 7 年(1527)建立 兒文 5 年 (1665)移築修理 重文)として現存する。同塔は宽文造営時に但馬国妙見山 日光院より本殷用材を入手したのと交換に誏渡された。絵図に描かれた建 築のうち唯一現存する。

10）千家前揭論文。

11）文献によって存在が推定されるが、絵図に見えないものは原則として復元 しなかった。

12）干家前揭論文による。同論文に全文を翻刻し、揭战する。

13）正保 3 年 6 月17日付「阿部忠秋备状」(『出雲国造家文暻』所収)。和田茄 有「宽文度の出雲大社造営についてー「大社造営一紙目録」を中心に一」 （『日本建筑学会中国支部研究報告等』平成 8 年度)による。なお、同詥文 では睍文度造営の造営経䋨、詳細な経貿の分析などが行われている。

14）稲垣、三浦、福本各氏は岛根県立図叟館所藏、影写本、「千家家文凅」に よっている。千家家所葴の原本の表題は「杵築大社只今御座候仮監造御宮 立間尺党」であり、県立図残館本に見られる「露州」の語はない。

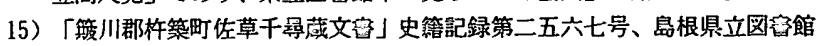

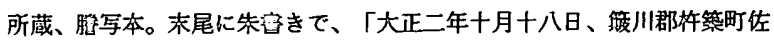

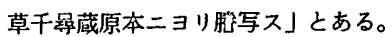

16）「口上之党」原本は箖府寺社奉行所へ提出され、その控が佐草千聂家に伝 わった。控の写本が千家家本であり(写本作成時期不明)、控の鹃写本が註 15 の図曾館本(大正 2 年作成)である。佐草千祦家本は後年所在不明。両者

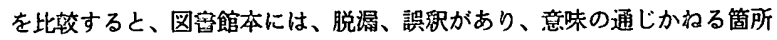
が見られる。本殿に関する引用部分では次のような異同がある。(千家家

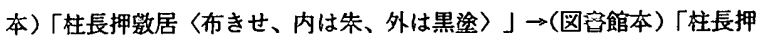
教居〈外八布きせ、内八朱黒㾞〉」。(千家家本)「彫物〈南破風二龍二疋

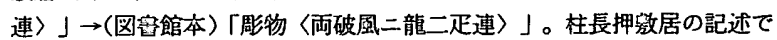
は、図客館本は意味が通じず誤写と思われる。彫物の記述では、(千家家 本)「南破風」之(図客館本)「両破風」の異同があるが、ここでは千家家 本にしたがった。島根県立古代文化センター岡宏三氏の御教示による。

17）堌文元年 8 月より同 3 年12月までは写本一冊か現存。宽文 4 年正月より同 4 年 5 月 5 日まで一冊、罟文 4 年 5 月 6 日より同 6 月11日まで一冊、宽文 4 年 6 月 12 日より同 4 年 9 月 10 日まで一冊、究文 5 年 7 月 15 日より同 5 年 8月26日まで一冊、計四冊は佐草自清自簕の原本が現存する。これらは島 根県大社町大社町史鶭篹委員会がマイクロフィルム报影し、『名草神社三 重塔と出雲大社』(山田宗之ほか、私家版、1995)に袳刻されている。

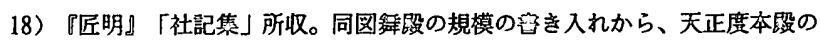
指図と判明する(前揭福山「出雲大社の社殿」)。

19）佐草自消著 昼享 3 年(1686)、『神道大系』神社缩37 出室大社 所收。

20）三浦前揭論文による。なお、「出露国造系譄芳」は唇長度本殿について、 「蓋康長年中仮殿造営之時(中略)且又御本殿出組造二重垂不彫物等、皆以 非古制也、踓饭殿造為後戒洝注之矣」と記す。

21）福苯前揭論文。

22）「御造営日記」宽文 2 年 2 月29日条。註 7 参照。

23）「御造営日記」宽文 4 年 7 月 13 日集(本文前揭)。不形は現存し、出露大社 神祐殿に展示されている。

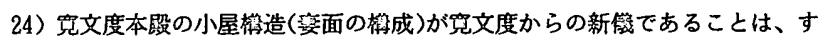
でに川上前揭論文に指摘されており、本馠の論点も同論文によるところが 大きい。

25）「杵築大社近楖絵図」四图 18 に担首棹は見られない。提首棹が算かった 可能性もあるが、把首棹を入れたのは、虹梁に槙束だけでは、柯造的にか

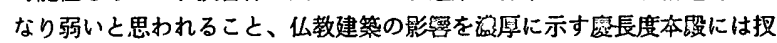
首棹を入れた方がふさわしいと思われること、による。

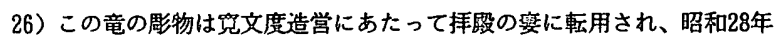
（1953）に焼失するまで存在した。旧拝殷势および龍䧓物の写真は、『プレ 古代出雲文化展 サイエンスロマン“I Z U MO” 一古代出雲文化展への 招待一』(島根県立八雲立つ風土記の丘編 1997)に掲哉されている。

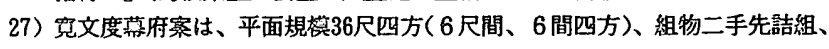
中備烈股、縁腰組插时不四手先、安二重虹梁大瓶束である。

28）川上前揭論文によれば、宽永21年(1644)造営の日御碕神社社殷の設計图 「日御碕神社社殿建地割図」(日御倚神社所藏前揭『古図にみる日本の建

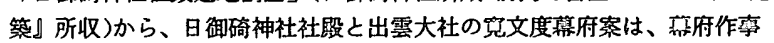
方披官大工槽梁乑の関与、紐部意匠、などの一致点が指摘できる。

29）和田前掲論文。

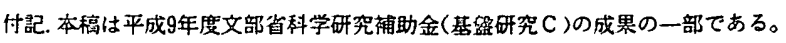

